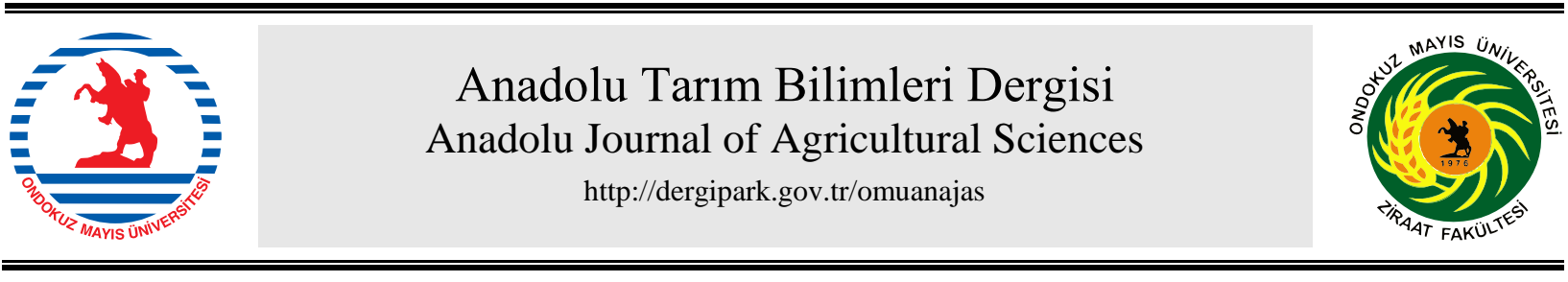

Araştırma/Research

Anadolu Tarım Bilim. Derg./Anadolu J Agr Sci, 33 (2018)

ISSN: 1308-8750 (Print) 1308-8769 (Online)

doi: 10.7161/omuanajas.310249

\title{
Terme Yöresi alüviyal arazilerde yetiştirilen çeltiğin bazı fiziko-kimyasal toprak özellikleriyle besin element kapsamı arasındaki ilişkiler
}

\author{
Ayhan Horuz*, Orhan Dengiz \\ Ondokuz Mayıs Üniversitesi, Ziraat Fakültesi, Toprak Bilimi ve Bitki Besleme Bölümü, Samsun \\ *Sorumlu yazar/corresponding author: ayhanh@omu.edu.tr
}

Geliş/Received 03/05/2017 Kabul/Accepted 01/12/2017

\begin{abstract}
ÖZET
Çeltik bölgede ekonomik değere sahip ürünlerin başında gelmektedir. Çeltikten optimum verimin alınabilmesi için her şeyin başında arazinin toprak özellikleri ve besin kapsamının çok iyi bilinmesi gerekir. Aksi takdirde ciddi verim kayıplarının yaşanması kaçınılmazdır. Bu çalışmanın amacı Samsun ili Terme yöresinde çeltik yetiştirilen alüviyal arazilerde yayılım gösteren toprakların fiziko kimyasal özellikleri ve besin element kapsamı arasındaki ilişkileri belirlemektir. Çalışma alanından alınan 64 toprak örneği analiz sonuçlarına göre değerlendirilmiş ve istatistiksel olarak yorumlanmıştır. Elde edilen sonuçlara göre, toprakların kil kapsamı \%19.8-67.7; silt kapsamı \%14.5-32.0; kum kapsamı \%1.7-65.7; organik madde \% 0.63-4.87; tuz içeriği 0.08-1.66 dS/m; pH 5.16-7.45 ve kireç \% 0.58-1.94; arasında değişmiştir. Besin element kapsamı bakımından ise, yarayışlı fosfor (P) 5.30-46.90 ppm; alınabilir potasyum (K) 45.0-635.0 ppm; yarayışlı demir (Fe) 5.03-212.30 ppm; mangan (Mn) 6.1191.32 ppm; çinko $(\mathrm{Zn})$ 0.03-1.36 ppm; bakır $(\mathrm{Cu}) 3.83-15.90 \mathrm{ppm}$ ve bor $(\mathrm{B})$ 0.02-1.24 ppm arasında değişmiştir. Toprak özellikleri ve besin element kapsamı arasındaki ilişkilere göre, toprakların kil kapsamı ile silt ve kum kapsamı arasında negatif, organik madde (OM) ve Mn kapsamı arasında ise negatif; kum kapsamı ile OM ve Mn kapsamı arasında negatif; OM ile Cu kapsamı arasında pozitif; tuz içeriği ile K kapsamı arasında pozitif; $\mathrm{pH}$ ile $\mathrm{P}, \mathrm{K}$ ve $\mathrm{Cu}$ kapsamı arasında pozitif, Mn kapsamı arasında negatif önemli ilişkiler elde edilmiştir. P kapsamı ile $\mathrm{K}, \mathrm{Zn}$ ve $\mathrm{Cu}$ kapsamı arasında; K kapsamı ile $\mathrm{Zn}$ ve $\mathrm{Cu}$ kapsamı arasında önemli pozitif ilişkiler elde edilmiştir. Sonuç olarak yöre çeltik topraklarının organik maddece zenginleştirilmesi, tuzluluk seviyesine dikkat edilerek $\mathrm{P}, \mathrm{K}, \mathrm{Zn}$ ve B içeren gübrelerin verilmesi önerilmiştir. Ayrıca toprakların büyük bir çoğunluğunun nispeten düşük pH'ya sahip olması nedeni ile ileride oluşabilecek muhtemel Fe ve Mn toksitesine karşı kireç uygulaması tavsiye edilmiştir.
\end{abstract}

\section{The Relationships Between Some Physico-chemical Properties and Nutrient Element Content of Paddy raised on Alluvial Land in Terme Region}

\section{ABSTRACT}

The rice is one of the most important yields, which has valuable income for regional economy. In order to obtain optimum yield from rice cultivation, it should be known soil properties and nutrition content of land in which rice has been grown. Otherwise, it can be faced with deprivation of yield due to misuse or applications for rice land management. The objective of this study was to determine relationships between physic-chemical properties of soil located on alluvial lands and nutrient elements in Terme district of Samsun province. For this purpose, 64 soil samples collected from the study area was statistically evaluate. The clay, silt and sand content of soils varied between 19.8-67.7\%, 14.5-32.0\% and $1.7-65.7 \%$, respectively. In addition, organic matter, salt, $\mathrm{pH}$ and lime content were found as $0,63-$ 4,87\%, 0.8-1.66 dS/m, 5.16-7.45 and 0.58-1.94, respectively. Moreover, micro and micro nutrient element contents were determined as 5.30-46.90 ppm, 45.0-635.0 ppm, 5.03-212.30 ppm, 6.11-91.32 ppm, 0.03-1.36 ppm, 3.83-15.90 ppm and 0.02-1.24 ppm for available P, exchangeable K, available Fe, $\mathrm{Mn}, \mathrm{Zn}, \mathrm{Cu}$ and $\mathrm{B}$, respectively. It was found that there were significantly important relationships between clay content of soils and silt, sand, organic matter and $\mathrm{Mn}$ contents. Besides, there are significant relationships between sand and $\mathrm{OM}$, and $\mathrm{Mn}$ content. Another significant relation was also determined between $\mathrm{OM}$ and $\mathrm{Cu}$ content. Other significant relations are between salt and $\mathrm{K}$ content; between $\mathrm{pH}$ and $\mathrm{P}, \mathrm{K}, \mathrm{Mn}$ and $\mathrm{Cu}$ contents, and between $\mathrm{P}$ content and $\mathrm{K}, \mathrm{Zn}, \mathrm{Cu}$ content and between

Anahtar Sözcükler:

Çeltik toprağ 1

Alüviyal arazi

fiziko kimyasal özellik

Besin element kapsamı
Keywords:

Paddy soil

Alluvial land

Physico-chemical

properties

Nutrient elements 
$\mathrm{K}$ content and $\mathrm{Zn}, \mathrm{Cu}$ content. Consequently, it should be given some suggestions such as application of fertilizers including $\mathrm{P}, \mathrm{K}, \mathrm{Zn}$ and $\mathrm{B}$ by taking into consideration of salinity level of soils and enrichment of organic matter in the paddy fields. Also, it was recommended to apply lime against potential $\mathrm{Fe}$ and $\mathrm{Mn}$ toxicity that may occur in the future, due to the fact that a large majority of soils have low $\mathrm{pH}$ values.

\section{Giriş}

Çeltik su içerisinde çimlenen, kökleri suda erimiş oksijenden yararlanabilen tek tahıl cinsi olup buğdaygiller (Gramineae) familyasından, Oryza sativa L. cinsinden otsu bir bitki türüdür. Besin kaynağı olarak buğdaydan sonra en önemli kültür bitkisidir (Temür, 2016). Ayrıca Dünyada kişi başına günlük enerjinin \%25'i çeltik tüketimi ile karşılanmaktadır (Sürek, 2002).

Tarımsal üretimde asıl amaç bitkisel verimliliği artırmaktır. Bu amaca ulaşmada elde edilecek başarı, bitki için gerekli yaşam ortamını, yani toprağı verimli düzeye çıkarmaya bağlıdır. Toprağı verimli düzeye çıkarmak dediğimizde aklımıza toprağın fiziksel, kimyasal ve biyolojik özelliklerini iyileştirmek gelir. Toprağın bu özelliklerini geliştiren birçok faktör vardır. Örneğin organik maddenin, bitki besin maddeleri ile birlikte toprakların fiziksel ve biyolojik özelliklerine yaptığı katkı bakımından önemi büyüktür (Kacar, 1997).

Tarımsal üretimde verim üzerine etki eden en önemli faktörlerin başında toprak verimliliği gelir. Bazı koşullarda besin elementi fazlalığı veya besin elementi yetersizliği bitkiler tarafindan diğer besin elementlerinin alınmasına engel olurken, verim ve kaliteyi de olumsuz yönde etkilemektedir. Öte yandan yörede etüd çalışmaları ile toprakların fiziksel ve kimyasal özellikleri belirlenerek, bu özellikler ile topraktaki besin elementleri arasındaki ilişkilerin bilinmesi, yapılacak gübreleme programları ile en yüksek faydanın sağlanması açısından önemli olacaktır (Çimrin ve Boysan, 2006).

Toprak kimyası ve verimlilik araştırmalarının genel amacı, bitki gelişimiyle ilişkili olarak topraklardaki kimyasal ve biyokimyasal reaksiyonlarının temelinin iyi bir şekilde anlaşılması ile toprak ve çevre kalitesinde sürdürülebilirliğin korunmasını sağlamaktır (Sağlam ve Dengiz, 2013). Sürdürülebilir tarımsal üretimde en önemli faktör toprakların bozulmasına sebebiyet vermeden toprakların üretkenliğini artırarak, verimlilik parametrelerinde kalitesinin devamlılığının sağlanmasıdır. $\mathrm{Bu}$ da ancak tarımsal üretim alanlarında toprağın fiziksel, kimyasal ve biyolojik özelliklerinin değişimine neden olan etkin süreçlerin belirlenmesi ve gerekli tedbirlerin alınması ile gerçekleştirilebilir. Bitkiler tarafindan topraklardan sömürülen bitki besin maddelerinin yeniden toprağa kazandırılması günümüzde tarımsal sürdürülebilirliğin en yaygın uygulamasıdır (Akça vd., 2015).

Başar (2001), Bursa ilinde farklı tarım ürünlerinin yetiştirildiği arazilerden alınan 1018 adet toprak örneğinde yaptığı araştırma sonuçlarına göre, toprakların \%56.49'unun organik madde, \%21.81'inin alınabilir P ve \% 21.82'sinin alınabilir K kapsamlarının düşük ve çok düşük düzeylerde olduğu bildirilmiştir. Zengin vd. (2003), Konya İli Beyşehir İlçesi tarım topraklarının verimlilik durumlarını belirlemek amacı ile alınan 48 adet toprak örneğinde $\mathrm{N}, \mathrm{P}, \mathrm{K}, \mathrm{Fe}, \mathrm{Cu}, \mathrm{Mn}$ ve $\mathrm{Zn}$ ortalama değerlerinin sirasıly $104.73,24.48$, $502.9, \quad 15.62, \quad 5.84,2.74$ ve $2.62 \mathrm{ppm}$ olduğunu bildirmişlerdir.

Toprağın doğal verimliliğinin korunmasında esas kimyasal girdilerin en az düzeyde tutularak çevresel faktörlerin değerlendirilmesidir (Karaman vd., 2012). $\mathrm{Bu}$ nedenle her hangi bir alan içerisinde yer alan bir birimden farklı özelliklere sahip toprakların fiziksel, kimyasal ve verimlilik gibi temel özelliklerinin bilinmesi ve her toprak çeşidinin taşımış olduğu karakteristik yapısına göre yönetilmesi gerekmektedir. $\mathrm{Bu}$ bağlamda alüviyal arazilerde yer alan topraklar, akarsularla taşınmış sediment materyaller üzerinde oluşmaları nedeniyle kısa mesafeler içerisinde ani değişkenlikler gösterebilmektedirler. Turan vd. (2010), Bursa ili alüviyal araziler üzerinde yer alan tarım topaklarının genel olarak orta bünyeli, hafif alkali reaksiyonlu $(\mathrm{pH})$ olduğu, az ve orta düzeyde kireç içeren toprakların \%43.39'unun organik madde, \%46.66'sının toplam N, \%10'unun yarayışlı $\mathrm{P}$, \%43.34'ünün yarayışlı $\mathrm{Zn}$ ve \%90'ının yarayışlı Mn bakımından yetersiz olduğunu bildirmişlerdir. Ayrıca toprakların \%23.33'ünde alınabilir K, \%43.33'ünde yarayışlı $\mathrm{Ca}, \% 73.33$ 'ünde alınabilir $\mathrm{Mg}, \% 50$ 'sinde alınabilir $\mathrm{P}, \% 90$ 'ında yarayışlı $\mathrm{Fe}$ ve tamamında yarayışlı $\mathrm{Cu}$ miktarının yeterli olduğunu bildirmiş̧lerdir.

Bu çalışmanın amacı, Samsun ili Terme yöresinde yayılım gösteren alüviyal çeltik arazilerinin bazı fiziko kimyasal toprak özellikleri ile besin element kapsamı arasındaki ilişkileri ortaya koymaktır.

\section{Materyal ve Yöntem}

Çalışma Samsun ilinin Terme ilçesi sınırları çerisinde ve Çarşamba Ovasının doğusunda yer alan Terme Çayının Çarşamba Ovasına girdiği yer ile denize döküldüğg̈ yaklaşık $20 \mathrm{~km}$ 'lik mesafede çayın her iki yakas1 arasındaki $53.6 \mathrm{~km} 2$ genişlik kaplayan alan içerisinde gerçekleştirilmiştir. Samsun İli Orta Karadeniz Bölgesinde bulunan Terme ilçesi; yüzölçümü $583 \mathrm{~km}^{2}$ olup, Terme Çayı kenarında ve denizden $3 \mathrm{~km}$ içeride kurulmuştur (Şekil 1).

Terme'de her mevsim yağışı tipik Karadeniz iklimi hüküm sürmektedir. Terme ilçesine en yakın Ünye 17624 nolu rasatının 1960-2014 yılları aras1 verilerine göre, yıllık ortalama yağış miktarı $964.8 \mathrm{~mm}$ olup en fazla Kasım ayında en düşük ise $52.7 \mathrm{~mm}$ ile Mayıs ayında ölçülmüsştür. İlçenin sıcaklık durumu ise 
ortalama yillık sicaklık durumu $14.3{ }^{\circ} \mathrm{C}$ ve en sicak ay $23.2{ }^{\circ} \mathrm{C}$ ile Ağustos ve en düşük sicaklık ise $6.8^{\circ} \mathrm{C}$ ile Şubat ayında ölçülmüştür Çalışma alanında yer alan çeltik arazilerini temsilen 0-30 toprak derinliğinden toplam 64 adet toprak örneği alınmıştır (Şekil 2). Alınan toprak örnekleri hava kuru hale getirildikten sonra, 2 mm'lik elekten geçirilerek, fiziksel ve kimyasal analizlere hazır hale getirilmiştir.

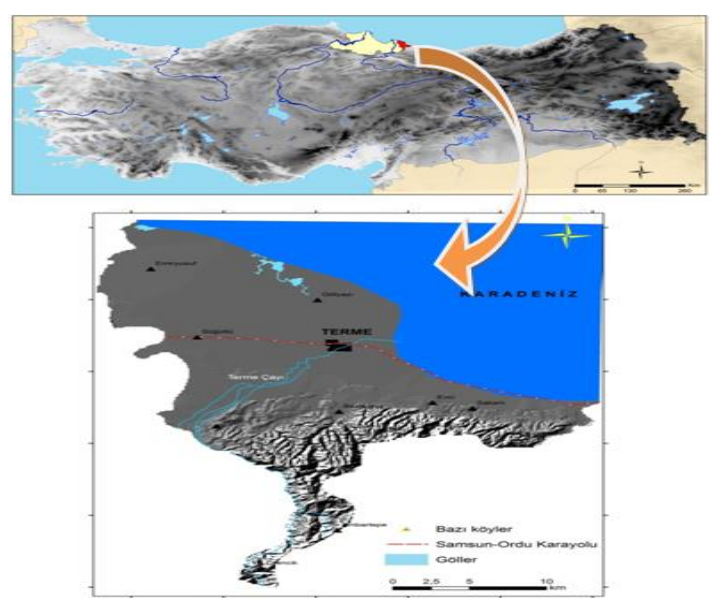

Şekil 1. Çalışma alanı lokasyon haritası

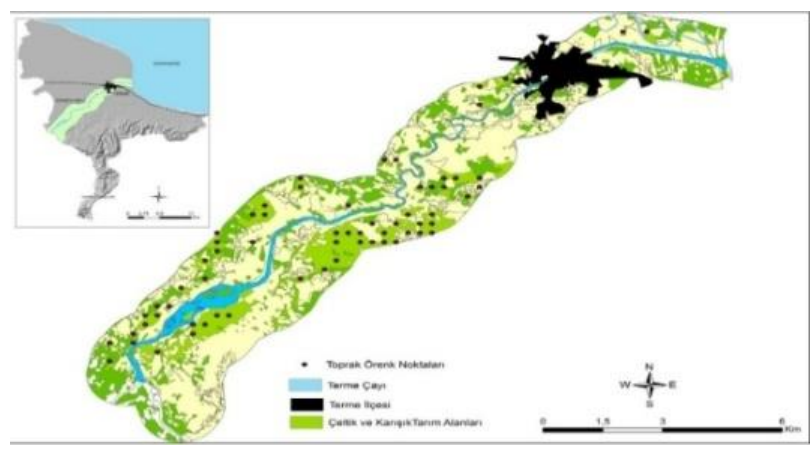

Şekil 2. Çalışma alanı içerisinde dağılım gösteren çeltik arazilerinden alına toprak örnek yerleri

Araştırma materyalini oluşturan toprak örneklerinde bünye hidrometre yöntemi (Bouyoucous, 1951); kirec Scheibler kalsimetresi (Soil Survey Staff, 1993); toprak reaksiyonu $(\mathrm{pH})$ ve tuz içeriği saturasyon çamurunda (Soil Survey Labrotory, 1992); organik madde modifiye Walkley-Black yöntemine göre (Jackson, 1967); alınabilir potasyum $1 \mathrm{~N}$ amonyum asetat (NH4OAc) metodu ile belirlenmiştir (Suarez ve Vaughan, 2001). Yarayışlı fosfor $\mathrm{pH}>7$ topraklar $0.5 \mathrm{M} \mathrm{NaHCO} 3$ ile Olsen vd. (1954) metoduna göre; $\mathrm{pH}<7$ topraklar $0.03 \mathrm{~N}$ $\mathrm{NH} 4 \mathrm{~F}+0.025 \mathrm{~N}$ HCI ile Bray ve Kurtz No.1 metoduna göre (Bray ve Kurtz, 1945) belirlenmiştir. Yarayışlı çinko, demir, mangan ve bakır 0,005 M DTPA metoduna göre Perkin Elmer, AA-400 Atomik Absorbsiyon Spektrofotometresinde (Lindsay ve Norvell 1978); yarayışlı bor sıcak su ekstraksiyonunda Azometin-H yöntemine göre spektrofotometrede belirlenmiştir (John vd, 1975).

Toprakların bazı fiziko kimyasal özellikleri ve yarayışlı besin element kapsamına ait verimlilik ilişkilerinin ortaya konulmasında tanımsal istatistik ve korelasyon analizleri (SPSS 17.0) kullanılarak Düzgüneş vd. (1987)'e göre yorumlanmıştır.

\section{Bulgular ve Tartışma}

Tanımlayıc1 istatistik tablosundan (Çizelge 1) anlaşılacağı üzere incelenen toprak özelliklerine ait çarpıklık katsayıları veri setinin büyük oranda normal dağılım (kil, OM, pH, kireç, toplam $\mathrm{N}, \mathrm{Mn}$ ve $\mathrm{Cu}$ ) sergilerken, bazı toprak özelliklerinin ise pozitif çarpıklık katsayısına (kum, tuz, P, K, Fe, Zn ve B) sahip olduğu görülmektedir (Webster, 2001).

\subsection{Toprakların genel özellikleri}

Samsun yöresi alüvyal çeltik topraklarının bazı fiziksel ve kimyasal özellikleri ile makro ve mikro besin element kapsamı Çizelge 1'de verilmiştir. Çizelge incelendiğinde araştırma topraklarının kil, silt ve kum içeriği sırasıyla \% $19.8-67.7,14.5-32.0$ ve $1.7-65.7$ arasında değişmekte olup, ortalama \% 43.5 kil, \% 58.8 silt ve \% 24.5 kum içerdiği bulunmuştur.

Toprakların büyük çoğunluğunun killi ve siltli bünyeye sahip oldukları bulunmuştur. Bouyoucos (1951)'un bünye sinıflarına göre toprakların $\% 56.25$ ' $\mathrm{i}$ killi, \% 31.25'i killi tınlı, \% 6.25'i siltli kil, \%1.56's1 tınlı, \%1.56's1 siltli tın, \% 1.56 's1 kumlu tın ve \%1.56's1 kumlu killi tın bünyede oldukları tespit edilmiştir (Çizelge 2).

Yöre çeltik topraklarının tuz içeriği \% 0.08-1.66 arasında değişmekte ve ortalama \% 0.44 tuz içermektedir (Çizelge 1). Richard (1954)'e göre toprakların \%9.38'i az tuzlu, \% 31.25'i hafif tuzlu, \% 45.31 'i orta tuzlu ve \% 14.06 's1 fazla tuzlu sinıfina girdikleri tespit edilmiştir (Çizelge 2). Çeltik topraklarının reaksiyonu $\mathrm{pH}$ 5.16-7.45 arasinda değişmekte, ortalama pH 6.40'dır (Çizelge 1). Richard (1954)'e göre toprakların \% 6.25'i kuvvetli asit (5.15.5), \% 18.75'i orta derecede asit (5.6-6.0), \% 23.44'ü hafif asit (6.1-6.5), \% 50'si nötr (6.6-7.3) ve \% 1.56's1 hafif alkalin (7.4-7.8) reaksiyonlu oldukları tespit edilmiştir (Çizelge 2).

Çeltik topraklarının OM içeriği 0.63-4.87 arasında değişmekte olup, ortalama \%2.58 OM kapsadığ bulunmuştur (Çizelge 1). Horuz (1996)'ya göre toprakların \% 12.50'si çok az, \% 54.69'u az, \% 20.31'i orta, \% 4.69'u yükssek ve \%7.81'i çok yüksek organik madde içerdiği tespit edilmiştir. (Çizelge 2). Turan vd (2010) Bursa ili alüviyal topraklarının da organik madde bakımından çoğunlukla az sınıfına girdiğini bildirmişlerdir. Çeltik topraklarının kireç içerikleri \% 0.58-1.94 arasında değişmekte, ortalama \%1.19 kireç içermektedir (Çizelge 1). Ülgen ve Yurtsever (1988)'e göre toprakların \% 31.25 'i kireçsiz ve $\% 68.75$ 'i kireçli oldukları tespit edilmiştir (Çizelge 2). 
Toprakların kil ile silt içeriği arasında önemli ($\left.0.318^{*}\right)$ ve kum içeriği arasında ise çok önemli ($0.722 * *)$ negatif; OM içeriği $(0,291 *)$ ile önemli pozitif ilişkiler bulunmuştur. Silt içeriği ile kum içeriği ($0.427^{* *}$ ) arasında çok önemli; kum içeriği ile OM içeriği $\left(-0.275^{*}\right)$ arasında önemli negatif ilişki bulunmuştur (Çizelge 3). Benzer sonuçlar farklı araştırmacılar tarafından da bildirilmiştir(Atalay, 1988; Horuz ve Korkmaz, 2000; Çimrin ve Boysan, 2006; Kacar vd., 2006; Turan vd., 2010).

Çizelge 1. Çeltik topraklarının bazı fiziko kimyasal özellikleri ve besin element kapsamı

\begin{tabular}{lcccccccc}
\hline $\begin{array}{l}\text { Toprak } \\
\text { özelliği }\end{array}$ & Ortalama & Minimum & Maksimum & $\begin{array}{c}\text { Standart } \\
\text { sapma }\end{array}$ & Varyans & Çarpıklık & Basıklı & $\mathrm{n}$ \\
\hline Kil, \% & 43.48 & 19.80 & 67.70 & 9.74 & 94.89 & 0.02 & 0.14 & 64 \\
Silt, \% & 32.04 & 14.50 & 58.80 & 7.46 & 55.60 & 0.55 & 1.92 & 64 \\
Kum, \% & 24.48 & 1.70 & 65.70 & 10.21 & 104.30 & 1.12 & 3.04 & 64 \\
Tuz, \% & 0.44 & 0.08 & 1.66 & 0.30 & 0.09 & 2.26 & 6.56 & 64 \\
pH & 6.40 & 5.16 & 7.45 & 0.55 & 0.30 & -0.35 & -0.49 & 64 \\
OM, \% & 2.58 & 0.63 & 4.87 & 1.01 & 1.03 & 0.27 & -0.32 & 64 \\
Kireç, \% & 1.19 & 0.58 & 1.94 & 0.33 & 0.11 & 0.11 & -0.33 & 64 \\
P, ppm & 18.83 & 5.30 & 46.9 & 8.77 & 76.85 & 0.95 & 0.66 & 64 \\
K, ppm & 145.74 & 45.00 & 635.00 & 87.81 & 7711.25 & 3.03 & 13.45 & 64 \\
Fe, ppm & 50.89 & 5.03 & 212.30 & 50.43 & 2543.50 & 1.76 & 2.06 & 64 \\
Mn, ppm & 49.02 & 6.11 & 91.32 & 21.47 & 460.92 & 0.23 & -0.74 & 64 \\
Zn, ppm & 0.32 & 0.03 & 1.36 & 0.23 & 0.05 & 2.49 & 7.54 & 64 \\
Cu, ppm & 10.59 & 3.83 & 15.90 & 2.76 & 7.63 & -0.16 & -0.49 & 64 \\
B, ppm & 0.30 & 0.02 & 1.24 & 0.26 & 0.07 & 1.56 & 2.75 & 64 \\
\hline
\end{tabular}

OM: Organik madde; P: Yarayışlı fosfor; K: Alınabilir potasyum; Yarayışı Fe (demir), Mn (mangan), Zn (çinko), Cu (bakır), B (bor); n: Örnek sayısı.

Tuz (EC) bakımından topraklar \% $0.08-1.66$ tuz içermekte ve ortalama tuz içeriği $\% \quad 0.44$ 'dür. Toprakların reaksiyonu $\mathrm{pH} 5.16-7.45$ arasinda değişmekte, ortalama pH 6.40'dır. 64 nolu toprak örneği hafif alkalin reaksiyonda iken diğer örneklerin nötr, hafif ve orta asit pH'ya sahip oldukları bulunmuştur. Toprakların kireç içerikleri \% $0.58-1.94$ arasında değiştiği, ortalama \% 1.19 olduğu ve tüm topraklar kireçsiz bulunmuştur (Çizelge 1). Ayrıca, toprakların kil ile silt içeriği arasında önemli $\left(-0,318^{*}\right)$ ve kum içeriğ arasında ise çok önemli $(-0,722 * *)$ negatif; OM içeriği $\left(0,291^{*}\right)$ ile önemli pozitif ilişkiler bulunmuştur. Silt içeriği ile kum içeriği $\left(-0,427^{* *}\right)$ arasında çok önemli; kum içeriği ile OM içeriği $\left(-0,275^{*}\right)$ arasında önemli negatif ilişki bulunmuştur (Çizelge 2). Benzer sonuçlar farklı araştırmacılar tarafından da bildirilmiştir (Atalay, 1988; Horuz ve Korkmaz, 2000; Çimrin ve Boysan, 2006; Kacar ve ark., 2006).

\subsection{Toprakların besin element kapsamı}

Yörede çeltik yetiştirilen alüviyal toprakların yarayış̧ı $\mathrm{P}, \mathrm{K}, \mathrm{Fe}, \mathrm{Mn}, \mathrm{Zn}, \mathrm{Cu}$ ve $\mathrm{B}$ besin element kapsamı Çizelge 1'de verilmiştir.

Toprakların yarayışı ı fosfor kapsamı 5.30-46.90 ppm arasında değişmekte, ortalama $18.83 \mathrm{ppm}$ yarayışlı $\mathrm{P}$ kapsamaktadır (Çizelge 1). $\mathrm{pH}>7$ topraklar Yurtsever ve
Alkan (1975)'ın bildirdiği sınır değerlerine göre değerlendirildiğinde \% 6.25'i iyi, \% 1.56'sı yüksek ve $\%$ 4.69'u yüksek seviyede fosfor içerirken; $\mathrm{pH}<7$ topraklar Olsen ve Sommers (1982)'nın bildirdiği sınır değerlerine göre değerlendirildiğinde ise toprakların \% 3.12 'si az, \% 51.56's1 orta ve \% 32.81'i yüksek seviyede yarayışlı fosfor içermektedir (Çizelge 4). Belirtilen değerlere göre toprakların büyük bir çoğunluğunun orta seviyede fosfor içerdiği bulunmuştur. Bu sonuçlara göre Samsun yöresi alüviyal çeltik topraklarının büyük çoğunluğunun fosforlu gübreye gereksinim duyduğu söylenebilir. Benzer şekilde Taban vd. (2004) Bursa yöresi alüviyal topraklarının \% 40'ının fosforca fakir ve fosforlu gübre gereksinimi olduğunu bildirmişlerdir. Karaca ve Çimrin (2002) de benzer sonuçları bulduklarını ifade etmişlerdir. Toprak örneklerinin yarayışlı fosfor içeriği ile diğer toprak özellikleri arasındaki ilişkiler incelendiğinde; yarayışlı fosfor kapsamı ile $\mathrm{pH}$ $\left(0.516^{* *}\right)$, yarayışlı potasyum $\left(0.516^{* *}\right)$, çinko $\left(0.619^{* *}\right)$ ve Cu kapsamı $\left(0.355^{* *}\right)$ arasında çok önemli pozitif önemli ilişkiler belirlenmiştir (Çizelge 2). Benzer ilişkiler Atalay (1987), Turan vd. (2010), Horuz ve Korkmaz (2000) tarafindan da ifade edilmiştir. 
Çizelge 2. Toprakların bazı fiziko-kimyasal özelliklerinin dağılımı ve sınıflandırılması

\begin{tabular}{|c|c|c|c|c|}
\hline Toprak Özelliği & Sınır değer & Değerlendirme & Örnek sayıs1 & Dağılım, \% \\
\hline \multirow{7}{*}{$\begin{array}{c}\text { Bünye } \\
\text { (Bouyoucos, 1951) }\end{array}$} & - & Killi (C) & 36 & 56.25 \\
\hline & - & Killi tın (CL) & 20 & 31.25 \\
\hline & - & Siltli kil (SiC) & 4 & 6.25 \\
\hline & - & Tinlı (L) & 1 & 1.56 \\
\hline & - & Siltli tın (SiL) & 1 & 1.56 \\
\hline & - & Kumlu tın (SCL) & 1 & 1.56 \\
\hline & - & Kumlu killi tın (SCL) & 1 & 1.56 \\
\hline \multirow{4}{*}{$\begin{array}{c}\text { Tuz, \% } \\
\text { (Richard, 1954) }\end{array}$} & $0.00-0.15$ & Tuzsuz & 6 & 9.38 \\
\hline & $0.15-0.35$ & Hafif tuzlu & 20 & 31.25 \\
\hline & $0.35-0.65$ & Orta tuzlu & 29 & 45.31 \\
\hline & $>0.65$ & Çok tuzlu & 9 & 14.06 \\
\hline \multirow{10}{*}{$\begin{array}{c}\mathrm{pH} \\
\text { (Richard, 1954) }\end{array}$} & $<4.5$ & Fevkalade asit & - & - \\
\hline & $4.5-5.0$ & Çok kuvvetli asit & - & - \\
\hline & $5.1-5.5$ & Kuvvetli asit & 4 & 6.25 \\
\hline & $5.6-6.0$ & Orta derecede asit & 12 & 18.75 \\
\hline & $6.1-6.5$ & Hafif asit & 15 & 23.44 \\
\hline & $6.6-7.3$ & Nötr & 32 & 50.00 \\
\hline & $7.4-7.8$ & Hafif alkalin & 1 & 1.56 \\
\hline & $7.9-8.4$ & Orta derecede alkalin & - & - \\
\hline & $8.5-9.0$ & Kuvvetli alkalin & - & - \\
\hline & $>9.1$ & Çok kuvvetli alkalin & - & - \\
\hline \multirow{5}{*}{$\begin{array}{c}\text { OM, \% } \\
\text { (Horuz, 2002) }\end{array}$} & $<1.39$ & Çok az & 8 & 12.50 \\
\hline & $1.39-2.91$ & $\mathrm{Az}$ & 35 & 54.69 \\
\hline & $2.92-3.61$ & Orta & 13 & 20.31 \\
\hline & $3.62-4.22$ & Yüksek & 3 & 4.69 \\
\hline & $>4.22$ & Çok yüksek & 5 & 7.81 \\
\hline \multirow{5}{*}{$\begin{array}{c}\text { Kireç, \% } \\
\text { (Ülgen ve Yurtsever, 1988) }\end{array}$} & $0-1$ & Az kireçli & 20 & 31.25 \\
\hline & $1-5$ & Kireçli & 44 & 68.75 \\
\hline & $5-15$ & Orta kireçli & - & - \\
\hline & $15-25$ & Fazla kireçli & - & - \\
\hline & $>25$ & Çok fazla kireçli & - & - \\
\hline
\end{tabular}

Çizelge 3. Çeltik topraklarının fiziko kimyasal özellikleri ve besin element kapsamı arasındaki ilişkilere ait korelasyon katsayıları (r)

\begin{tabular}{|c|c|c|c|c|c|c|c|c|c|c|c|c|c|}
\hline & Silt & Kum & $\mathrm{OM}$ & Tuz & $\mathrm{pH}$ & Kireç & $\mathrm{P}$ & K & $\mathrm{Fe}$ & $\mathrm{Mn}$ & $\mathrm{Zn}$ & $\mathrm{Cu}$ & B \\
\hline Kil & $-.318^{*}$ & $-.722^{* * *}$ & $.291^{*}$ & . 150 & -.039 & .097 & -.072 & -.110 & -.097 & $.304^{*}$ & -.030 & .223 & -.085 \\
\hline Silt & & $-.427^{* *}$ & -.003 & .002 & -.011 & -.065 & -.124 & -.032 & -.166 & .049 & -.028 & -.034 & .139 \\
\hline Kum & & & $-.275^{*}$ & -.144 & .044 & -.043 & .158 & .127 & .214 & $-.323^{* *}$ & .048 & -.188 & -.020 \\
\hline $\mathrm{OM}$ & & & & .065 & .092 & .147. & .165 & .076 & .173 & -.025 & .195 & $.432^{* *}$ & -.168 \\
\hline Tuz & & & & & .184 & .038 & .089 & $.468^{* * *}$ & -.164 & .023 & .177 & .222 & -.154 \\
\hline $\mathrm{pH}$ & & & & & & .163 & $.261^{*}$ & $.391^{* *}$ & -.130 & $-.347^{* *}$ & .156 & $.518^{* *}$ & .232 \\
\hline Kireç & & & & & & & .141 & .061 & -.155 & .098 & .179 & .192 & -.003 \\
\hline $\mathrm{P}$ & & & & & & & & $.516^{* *}$ & .109 & -.013 & $.619^{* * *}$ & $.355^{* *}$ & .130 \\
\hline K & & & & & & & & & -.032 & -.200 & $.603^{* *}$ & $.251^{*}$ & -.026 \\
\hline $\mathrm{Fe}$ & & & & & & & & & & -.114 & .054 & -.160 & -.224 \\
\hline $\mathrm{Mn}$ & & & & & & & & & & & .050 & -.011 & .073 \\
\hline $\mathrm{Zn}$ & & & & & & & & & & & & .215 & -.067 \\
\hline $\mathrm{Cu}$ & & & & & & & & & & & & & -.149 \\
\hline
\end{tabular}

*:0.05 düzeyinde önemli; **:0.01 düzeyinde önemli 
Çizelge 4. Toprakların besin element kapsamı dağılımı ve sınıflandırılması

\begin{tabular}{|c|c|c|c|c|}
\hline Toprak Özelliği & Sınır değer, \% & Değerlendirme & $\begin{array}{l}\text { Örnek } \\
\text { sayıs1 }\end{array}$ & Dağılım. \% \\
\hline & $<4$ & $\mathrm{Az}$ & - & - \\
\hline $\mathrm{pH} \geq 7$ Topraklarda & $4-8$ & Orta & - & - \\
\hline \multirow[t]{2}{*}{ (Yurtsever ve Alkan, 1975) } & $8-16$ & İyi & 4 & 6.25 \\
\hline & $16-24$ & Yüksek & 1 & 1.56 \\
\hline \multirow[t]{2}{*}{ Fosfor, ppm } & $>24$ & Çok yüksek & 3 & 4.69 \\
\hline & $<3$ & Çok az & - & - \\
\hline \multirow{3}{*}{$\begin{array}{c}\mathrm{pH}<7 \text { Topraklarda } \\
\text { (Olsen ve Sommers, } 1982 \text { ) }\end{array}$} & $3-7$ & $\mathrm{Az}$ & 2 & 3.12 \\
\hline & $7-20$ & Orta & 33 & 51.56 \\
\hline & $>20$ & Yüksek & 21 & 32.81 \\
\hline \multirow{5}{*}{$\begin{array}{c}\text { Potasyum, ppm } \\
\text { (Fawzi ve El-Fouly, 1980) }\end{array}$} & $<150$ & Noksan & 40 & 62.50 \\
\hline & $150-200$ & Orta & 15 & 23.44 \\
\hline & $200-300$ & Yeter & 5 & 7.81 \\
\hline & $300-400$ & Fazla & 2 & 3.12 \\
\hline & $>450$ & Çok fazla & 2 & 3.12 \\
\hline \multirow{4}{*}{$\begin{array}{l}\text { Demir, ppm } \\
\text { (Loué, 1986) }\end{array}$} & $<10$ & Noksanlık riski yüksek & 1 & 1.56 \\
\hline & $10-20$ & Noksanlık riski orta & 15 & 23.43 \\
\hline & $20-150$ & Yeterli & 42 & 65.63 \\
\hline & $>150$ & Hidromorfik problem var & 6 & 9.38 \\
\hline \multirow{5}{*}{$\begin{array}{l}\text { Mangan, ppm } \\
(\mathrm{FAO}, 1990)\end{array}$} & $<4$ & Çok az & - & - \\
\hline & $4-14$ & $\mathrm{Az}$ & 1 & 1.56 \\
\hline & $14-50$ & Yeterli & 35 & 54.69 \\
\hline & $50-170$ & Fazla & 28 & 43.75 \\
\hline & $>170$ & Çok fazla & - & - \\
\hline \multirow{5}{*}{$\begin{array}{l}\text { Çinko, ppm } \\
\text { (FAO, 1990) }\end{array}$} & $<0.2$ & Cok az & 20 & 31.25 \\
\hline & $0.2-0.7$ & $\mathrm{Az}$ & 41 & 64.06 \\
\hline & $0.7-2.4$ & Yeterli & 3 & 4.69 \\
\hline & $2.4-8.0$ & Fazla & - & - \\
\hline & $>8$ & Çok fazla & - & - \\
\hline \multirow{2}{*}{$\begin{array}{c}\text { Bakır, ppm } \\
\text { (Follet, 1969) }\end{array}$} & $<0.2$ & Yetersiz & - & - \\
\hline & $>0.2$ & Yeterli & 64 & 100 \\
\hline \multirow{5}{*}{$\begin{array}{l}\text { Bor, ppm } \\
\text { (Volf, 1971) }\end{array}$} & $<0.4$ & Çok az & 46 & 71.88 \\
\hline & $0.4-0.9$ & $\mathrm{Az}$ & 16 & 25.00 \\
\hline & $1-2.4$ & Yeterli & 2 & 3.12 \\
\hline & $2.5-4.9$ & Fazla & - & - \\
\hline & $>5.0$ & Çok fazla & - & - \\
\hline
\end{tabular}

Toprakların alınabilir potasyum kapsamı 45.0-635.0 ppm arasında değişmekte ve ortalama $145.7 \mathrm{ppm} \mathrm{K}$ kapsamaktadır (Çizelge 1). Fawzi ve El-Fouly (1980)'nin bildirdiği sınır değerlerine göre toprakların $\%$ 62.50'i noksan; \% 23.44'ü orta, \% 7.81'i yeter, $\%$ 3.12'sinin de fazla ve çok fazla seviyede alınabilir potasyum içerdiği belirlenmiştir (Çizelge 4). Belirtilen değerlere göre toprakların çoğunun potasyumca noksan olduğu büyük bir çoğunluğunun da potasyumlu gübrelemeye ihtiyaç duyduğu tespit edilmiştir. Toprak örneklerinin alınabilir potasyum kapsamı ile diğer toprak özellikleri arasında ilişkiler incelendiğinde; alınabilir potasyum kapsamı ile $\mathrm{pH}\left(0.391^{* *}\right)$, tuz içeriği $\left(0.468^{* *}\right)$, yarayışlı $\mathrm{P}\left(0.516^{* *}\right), \mathrm{Zn}\left(0.603^{* *}\right)$ ve $\mathrm{Cu}$ kapsamı $\left(0.355^{* *}\right)$ arasında çok önemli pozitif ilișkiler belirlenmiştir (Çizelge 2). Benzer ilișkiler Atalay (1988) ve Horuz (1996) tarafindan da belirtilmiştir.
Toprakların yarayışlı Fe kapsamı 5.03-212.30 ppm arasında değişmekte ve ortalama $50.89 \mathrm{ppm} \mathrm{Fe}$ kapsamaktadır (Çizelge 1). Loué (1986)'nin bildirdikleri sınır değerlerine göre değerlendirildiğinde toprakların $\% 1.56$ 'sında $\mathrm{Fe}$ noksanlık riski yüksek, \%2.43'ünde noksanlık riski orta, \%65.63'ü yeterli ve $\% 9.38$ 'inde hidromorfik problem olduğu bulunmuştur (Çizelge 4). Korkmaz vd. (2010) Bafra, Çarşamba ve Suluova topraklarının DTPA ile ekstrakte edilebilir demir miktarına bağlı olarak fasulye bitkisinin demirli gübrelemeye cevabını araştırdıkları çalışmada toprakta kritik Fe miktarını 15.95 ppm olduğunu bildirmişlerdir. Bu kritik değere göre yöre çeltik topraklarının büyük bir çoğunluğunda demirin yeterli az bir kısmında demirin fazla olduğu tespit edilmiştir. Dolayısıyla çeltik topraklarında zaten indirgen (redüksiyon) ortam şartları hakim olduğundan dolayı, ana materyalden kaynaklanan Fe noksanlığı yok ise, demirin noksanlığı söz konusu değildir (Aktaş, 1994; Kacar ve Katkat, 2009; Turan ve 
Horuz, 2012). Toprakların yarayışlı Fe kapsamı ile kil, silt, tuz, $\mathrm{pH}$ ve kireç içeriği, yarayışlı $\mathrm{K}, \mathrm{Mn}, \mathrm{Cu}$ ve $\mathrm{B}$ kapsamı arasında önemli olmayan negatif, kum, OM, N, $\mathrm{P}$ ve $\mathrm{Zn}$ kapsamı arasında önemli olmayan pozitif ilişkiler bulunmuştur. Kacar vd. (2006) yarayışlı Fe ile $\mathrm{pH}$, kireç, $\mathrm{Mn}$ arasında negatif ilişkiler tespit etmişlerdir. Tarakçığlu vd. (2007) ve Turan vd. (2010) da benzer ilişkiler bulduklarını bildirmişlerdir.

Toprakların yarayışlı Mn kapsamı 6.11-91.32 ppm arasında değişmekte ve ortalama $49.02 \mathrm{ppm} \mathrm{Mn}$ kapsamaktadır (Çizelge 1). FA (1990) tarafindan bildirilen sınır değerlerine göre toprakların yarayışlı $\mathrm{Mn}$ kapsamının \% 1.56'sı az, \% 23.44'ü yeter, \% 65.63'ü fazla ve \% 9.38'i fazla seviyede Mn içerdiği tespit edilmiştir (Çizelge 4). Yörede sadece 1 toprakta Mn noksanlı̆̆g görülmüş, diğer toprakların Mn bakımından yeterli veya fazla olduğu bulunmuştur. Yarayışlı Mn bakımından fazla olan topraklarda $\mathrm{pH}$ düzenlemesi, kireç veya Mn ile antagonistik ilişkili olan gübreleme programlarıyla bu sorun giderilebilir. Zira birçok araştırmacı da topraklarda $\mathrm{Mn}$ fazlalığının giderilmesinden belirtilen uygulamaları tavsiye ettikleri görülmektedir (Aktaş, 1994; Horuz vd 2000; Kacar ve Katkat, 2009). Toprakların yarayışlı Mn kapsamı ile pH $\left(-0.347^{* *}\right)$ arasında çok önemli ve kum içeriği $(-0.323 *)$ arasında önemli negatif; kil içeriği $\left(0.304^{*}\right)$ arasında önemli pozitif ilişkiler bulunurken, çalışmada yarayışlı $\mathrm{K}$ ve Fe kapsamı arasında da önemli olmayan negatif ilişkiler tespit edilmiştir. Tosun vd (2006) da benzer ilişkileri ifade etmişlerdir.

Toprakların yarayışlı Zn kapsamı 0.03-1.36 ppm arasında değişmekte ve ortalama $0.32 \mathrm{ppm} \mathrm{Zn}$ kapsamaktadır (Çizelge 1). Zn kapsamı FAO (1990) tarafından bildirilen sınır değerlerine toprakların yarayışlı Zn kapsamının 31.25'i çok az, \% 64.06'sı az ve \% 4.69'u yeterli bulunmuştur (Çizelge 4). Bu sonuçlara göre yöre topraklarının büyük bir çoğunluğunun $\mathrm{Zn}$ bakımından yoksun oldukları ve çinkonun gübreleme programlarına alınması gerektiği tespit edilmiştir. Eyüpoğlu vd. (1996) Türkiye tarım topraklarının \% 49.83'ünün, Çakmak vd (1996) Konya havzasında toprakların \% 92'sinin, Özgüven ve Katkat (2002) Bursa ili topraklarının \% 37.5'inin, Çimrin ve Boysan (2006) Van yöresi tarım topraklarının \%88.5'inin $\mathrm{Zn}$ bakımından yoksul olduklarını bildirmişlerdir. Aynı şekilde farklı bölgelerde yapılan çalışmalarda da topraklarım $\mathrm{Zn}$ bakımından noksan olduğu bildirilmiştir (Karaçal ve Çimrin, 1997; Eyüpoğlu vd., 1996). Toprakların yarayışlı Zn kapsamı ile P $\left(0.619^{* *}\right)$ ve $\mathrm{K}\left(0.603^{* *}\right)$ kapsamı arasında çok önemli pozitif ilişkiler bulunmuştur. Ayrıca tuz, OM ve $\mathrm{Cu}$ kapsamı arasında da önemli olmayan pozitif ilişkiler tespit edilmiştir.

Toprakların yarayışlı $\mathrm{Cu}$ kapsamı 3.83-15.90 ppm arasında değişmekte ve ortalama $10.58 \mathrm{ppm} \mathrm{Cu}$ kapsamaktadır (Çizelge 1). Toprakların yarayışılı $\mathrm{Cu}$ kapsamı hem Follet (1969) hem de Viets ve Lindsay (1973)'in bildirdikleri sınır değerlerine göre \%100'ü $\mathrm{Cu}$ bakımında yeterli $(>0.2)$ bulunmuştur (Çizelge 4).
Samsun yöresi alüviyal çeltik topraklarının tamamının yeterli $\mathrm{Cu}$ içerdikleri ve $\mathrm{Cu}$ noksanlığı söz konusu olmadığı tespit edilmiştir. Çimrin ve Boysan (2006) Van yöresi topraklarının, Tarakçıŏlu vd. (2007) Ordu yöresi topraklarının, Turan vd (2010) Bursa yöresi topraklarının \%100'ünün bakırca yeterli olduğunu bildirmişlerdir. Diğer yandan $\mathrm{Cu}$ fazlalığı Baker ve Walker (1989), De Vos vd. (1991) gibi araştırmacılara göre, bitkilerin toprak üstü organlarına oranla kök büyümesinin gerileyebileciğini, duyarlı bitkilerde kök hücre plazma membranlarının zarar görmesi sonucu bitki kökünden dışarı potasyum salgılayarak, $\mathrm{K}$ noksanlığı gösterebileceğini bildirmişlerdir. Ayrıca toprakların yarayışlı $\mathrm{Cu}$ kapsamı ile $\mathrm{pH}\left(0.518^{* *}\right)$ ve OM içeriği $(0.432 * *)$ arasında çok önemli, yarayışlı $\mathrm{P}$ kapsamı $\left(0.355^{* *}\right)$ ile çok önemli ve K $\left(0.251^{*}\right)$ kapsamı ile önemli pozitif ilişkiler bulunmuştur. Bununla birlikte $\mathrm{Cu}$ kapsamı ile tuz, kireç ve $\mathrm{Zn}$ kapsamı arasında pozitif, Fe ve B kapsamı arasında negatif önemli olmayan ilişkiler tespit edilmiştir.

Toprakların yarayışlı B kapsamı 0.02-1.24 ppm arasında değişmekte ve ortalama $0.31 \mathrm{ppm} \quad \mathrm{B}$ kapsamaktadır (Çizelge 1). Toprakların yarayışlı B kapsamı Wolf (1971)'a göre değerlendirildiğinde toprakların \% 71.88'ü düşük, $\% 25.00$ 'i az ve $\% 3.12$ 'si yeterli düzeyde $\mathrm{B}$ içerdiği bulunmuştur (Çizelge 4). Elde edilen verilere göre yöredeki alüviyal çeltik topraklarının B bakımından düşük ve borlu gübrelemeye ihtiyaç duyduğu tespit edilmiştir. Ancak bor gübrelemesinde noksanlık ile toksitenin bıçak sırtı birbirine yakın olduğu unutulmayarak mutlaka toprak analiz sonuçlarına göre gübreleme yapılması gerekir. Horuz ve Korkmaz (2000), Tarakçığlu vd. (2003), Özkutlu vd. (2016) gibi araştırmacılar da Karadeniz bölgesi topraklarında $\mathrm{B}$ noksanlığı olduğunu bildirmişlerdir. Araştırmacıların ifadelerinden yörede geçmişten günümüze B noksanlığının hala devam ettiği anlaşılmaktadır. Bor bitkilerde hücre duvarı strüktürü ve hücre büyümesinde, kök gelişiminde, bitkide şeker ve karbonhidratların taşınımı için gerekli olan önemli bir elementtir (Abdollahi vd. 2010). Şiddetli noksanlığında kök ve yaprak gelişimi, çiçeklenme ve dolayısıyla meyve veya dane oluşumu zarar görür (Kacar ve Katkat, 2009; Turan ve Horuz, 2012). Toprakları yarayışlı B kapsamı ile $\mathrm{pH}$, silt içeriği ve $\mathrm{P}$ kapsamı arasında pozitif, tuz, OM, Fe ve $\mathrm{Cu}$ kapsamı arasında da negatif önemli olmayan ilişkiler bulunmuştur.

\section{Sonuçlar}

Samsun İli Terme yöresi alüviyal çeltik arazileri, toprak özellikleri bakımından, genellikle killi-siltli bünyede, organik madde bakımından az sınıfinda, toprakların çoğu orta derecede tuzlu, büyük bir çoğunluğu nötr $\mathrm{pH}$ 'ya sahip olmakla birlikte hafif-orta asit $\mathrm{pH}$ 'da ve kireçsiz oldukları bulunmuştur. Topraklar besin element kapsamı bakımından ise yarayışlı fosfor seviyesi orta, değişebilir potasyumca noksandır. Yarayışlı demirce yüksek, yarayışı mangan bakımından 
yeterli olmakla birlikte bazı topraklarda fazla $\mathrm{Mn}$ olduğu tespit edilmiştir. Ayrıca, yöre topraklarının $\mathrm{Zn}$ ve B bakımından noksan, bakır bakımından yeterli olduğu bulunmuştur.

Toprak özellikleri ile besin kapsamı arasındaki ilişkiler bakımından toprakların kil kapsamı ile organik madde $(\mathrm{OM})$ ve $\mathrm{Mn}$ kapsamı arasında; $\mathrm{OM}$ ile $\mathrm{Cu}$ kapsamı arasinda, $\mathrm{K}$ kapsamı ile tuz, $\mathrm{pH}, \mathrm{P}, \mathrm{Zn}$ ve $\mathrm{Cu}$ kapsamı arasında; fosfor kapsamı ile $\mathrm{pH}$, potasyum, çinko ve $\mathrm{Cu}$ kapsamı arasında çok önemli pozitif ilişkiler belirlenmiştir. Yarayışı $\mathrm{Zn}$ kapsamı ile $\mathrm{P}$ ve $\mathrm{K}$ kapsamı arasında; yarayışlı $\mathrm{Cu}$ kapsamı ile $\mathrm{pH}$ ve $\mathrm{OM}$ içeriği arasında çok önemli pozitif ilişkiler elde edilirken, yarayışlı Mn kapsamı ile pH arasında çok önemli negatif ilişki elde edilmiştir.

$\mathrm{Bu}$ sonuçlara göre yöre çeltik topraklarında artan tuzluluk seviyesine dikkat edilerek; organik maddece zenginleştirilmesi, topraklara $\mathrm{P}, \mathrm{K}, \mathrm{Zn}$ ve $\mathrm{B}$ içeren gübrelerin verilmesi ile birlikte $\mathrm{pH}$ 'nın düşük olduğu çeltik arazilerinde ilerde oluşabilecek $\mathrm{Fe}$ ve $\mathrm{Mn}$ toksitesine karşı kireçleme uygulamaları ile gerekli tedbirlerin alınması önerilmiştir.

\section{Kaynaklar}

Abdollahi, M., Eshghi, S., Tafazoli, E., 2010. Interaction of paclobutrazol, boron and zinc on vegetative growth, yield and fruit quality of strawberry (Fragaria $\times$ Ananassa Duch. Cv. Selva). J. Biol. Environ. Sci., 4(11): 67-75.

Akça, M.O., Türkmen, F., Taşkın, M.B., Soba, M.R., Öztürk, H.B., 2015. Ankara üniversitesi Kalecik araştırma ve uygulama çiftliği topraklarının verimlilik durumlarının incelenmesi. Toprak Bilimi ve Bitki Besleme Dergisi, 3(2): 54 - 63.

Aktaş, M., 1994. Bitki besleme ve toprak verimliliği, Ankara Üniv. Ziraat Fak. Yayınları No: 1361, 395 s., Ankara.

Atalay, İ. Z., 1987. Gediz havzası alüvyal topraklarının besin elementi durumu ve bunların bazı toprak özellikleri ile ilişkileri. Ege Üniv. Zir. Fak. Derg., 24(1): 61-74.

Atalay, İ.Z., 1988. Gediz havzası rendzina topraklarının besin elementi durumu ve bunların bazı toprak özellikleri ile ilişkileri. Ege Üniv. Zir. Fak. Derg., 25(2): 173-184.

Baker, A.J.M., Walker, P.L., 1989. Physiological responses of plant to heavy metals and the quantificetion of tolerance and toxicity. Chem. Speciation Bioavail. 1: 7-17.

Başar, H., 2001. Bursa İli topraklarının verimlilik durumlarının toprak analizleri ile incelenmesi. Uludağ Ünv. Zir. Fak. Derg., 15: 69-83

Bouyoucos,G.J., 1951. A recalibration of the hydrometer method for making mechanical analysis of soil. Agr. J., 43:439.

Bray, R.H., Kurtz, L.T., 1945, Determination of total, organic and available forms of phosphorus in soils. Soil Sci., 59: 39-45.
Bremner, J.M., Mulvaney, C.S., 1982. Nitrogen-Total. In: A.L. Page, R.H. Miller (Eds). Methods of soil analysis. Part 2. 2nd ed. Agron. Monogr. 9. ASA and SSSA, Madison, WI, pp: 595-624.

Çakmak, İ., Torun, B., Erenoğlu, B., Kalayc1, M., Yılmaz, A., Ekiz, H., Barun, H., 1996. Türkiye'de toprak ve bitkilerde çinko eksikliği ve bitkilerin çinko eksikliğine dayanıklılık mekanizmaları.Tr. Journal of Agriculture and Forestry (20): 13- 23.

Çimrin, K.M., Boysan, S., 2006. Van yöresi tarım topraklarının besin elementi durumları ve bunların bazı toprak özellikleriyle ilişkileri. Yüzüncü Y1l Üniversitesi Ziraat Fakültesi Tarım Bilimleri Dergisi, 16: 105-111.

De Vos, C.H.R., Schat, H., De Wall, M.A.M., Vooijs, R., Ernst, W.H.O., 1991. Increased resistance to copper-induced damage of root cell plasmalemma in copper tolerant Silene-cucubalus. Physiol. Plant, 82: 525-528.

Düzgüneş, O., Kesici, T., Kavuncu, O., Gürbüz, F., 1987. Araştırma ve deneme metotları (İstatistik metotlar1-II). Ankara Üniversitesi Ziraat Fakültesi Yayınları, 1021, 381s., Ankara.

Eyüpoğlu, F., 1999. Türkiye topraklarının verimlilik durumları. T.C. Başbakanlık Köy Hizmetleri Genel Müdürlüğü, Toprak ve Gübre Araştırma Enstitüsü Yayınları. Genel Yayın No: 220, Teknik Yayın No: T-67, 122 s., Ankara.

Eyüpoğlu, F., Kurucu, N., Talaz, S., 1996. Türkiye topraklarının bitkiye yarayışlı bazı mikro elementler $(\mathrm{Fe}, \mathrm{Cu}, \mathrm{Zn}, \mathrm{Mn})$ bakımından genel durumu. T.C. Başbakanlık Köy Hizmetleri Genel Müdürlüğü, Toprak ve Gübre Araştırma Enstitüsü Müdürlüğü, 72 s., Ankara.

FAO, 1990. Micronutrient. Assessment at the Country Level: An International Study.FAO Soil Bulletin by Mikko Sillanpaa. Rome.

Fawzi, A.F.A., El-Fouly, M.M., 1980. Soil and leaf analysis of potassium in different areas in different areas in Egypt. Editor A. Saurat and M.M. El Fouly. Role of Potassium in Crop Production. IPI, Bern, pp. 73-80.

Follet RH, 1969. Zn, Fe, Mn and $\mathrm{Cu}$ in Colorado Soils. $\mathrm{Ph}$. D. Dissertation. Colorado State University, Colorado.

Horuz, A., 1996. Terme Ünye findık bahçesi topraklarının besin element durumu ve bunların bazı toprak özellikleriyle olan ilişkileri. Ondokuz Mayıs Üniversitesi, Fen Bilimleri Enstitüsü, Yüksek Lisans Tezi, 118 s., Samsun.

Horuz, A., 2002. Bafra ve Çarşamba Ovalarında toprakların azot durumlarını belirlemekte kullanılan bazı kimyasal yöntemlerin mısır bitkisi yetiştirerek tarla denemeleriyle kalibrasyonları. ilişkileri. Ondokuz May1s Üniversitesi, Fen Bilimleri Enstitüsü, Doktora Tezi, 121 s., Samsun

Horuz, A., Korkmaz, A., 2000. Determination of nutrient status in hazelnut leaves sampled from Terme and Ünye regions. Proceedings of 
International Symposium on Desertification. 13-17 June, Konya - Turkey, pp. 465-470.

Jackson, M.L., 1967. Soil chemical analysis.prentice hall of englewood cliffs, New Jersey, USA.

John, M.K., Chuah, H.H., Neufeld, J.H., 1975. Application of improved azomethine-H method to the determination of boron in soils and plants. Analytical letters, 8: 559-568.

Kacar, B., 2009. Toprak analizleri. Nobel Yayınc1lik, 467 s., Ankara.

Kacar, B., 1970. Estimation of plant available phosphorus by the combination of different $\mathrm{H}_{2} \mathrm{SO}_{4}$ and $\mathrm{NH}_{4} \mathrm{~F}$ concentration in the Çukurova soils. Annales de L'Universite D'Ankara. Tome X, pp. 103-131. Ankara.

Kacar, B., 1997. Gübre Bilgisi. Ankara Üniversitesi Ziraat Fakültesi Yayınları No: 1490. Ders Kitabı No: 449. 705 s., Ankara.

Kacar, B., Katkat, A.V., Öztürk, Ş., 2006. Bitki Fizyolojisi (2. Bask1), Nobel Yayınları, 563 s., Ankara.

Kacar, B., Katkat, V., 2009. Bitki Besleme. Nobel Yayıncılık, 645 s., Ankara.

Karaca, S. Çimrin, K.M., 2002. Adi fiğ (Vicia sativa L.) + arpa (Hordeum vulgare L.) karışımında azot ve fosforlu gübrelemenin verim ve kaliteye etkisi", Yüzüncü Yıl Üniv. Ziraat Fak. Tarım Bilimleri Dergisi, 12 (1): 47-52.

Karaçal, İ., Çimrin, K.M., 1997. Yüzüncü Yıl Üniversitesi kampüs alanı toprak profillerinin $\mathrm{Zn}$ durumu ve bu elementin bazı toprak özellikleri ile ilişkileri. I. Ulusal Çinko Kongresi, 12-16 Mayıs, Eskişehir, s.123-130.

Karaman, M.R., Brohi, A.R., Müftüoğlu, N.M., Öztaş, T., Zengin, M., 2012. Sürdürülebilir toprak verimliliği, Koyulhisar Ziraat Odası Kültür Yayınları, 390 s., Tokat.

Korkmaz, A., Şendemirci, H.S., Horuz, A., 2010. Toprakların DTPA ile ekstrakte edilebilir demir miktarına bağlı olarak fasulye bitkisinin (Phaselous Vulgaris L. Var. Nanus) demirli gübrelemeye cevabı. Anadolu Tarım Bilimleri Dergisi, 25(3): 175-184.

Lindsay, W.L., Norvell, W.A., 1978. Development of a DTPA test for zinc, 1ron, manganese and copper. J. Soil Sci. Am., 42: 421-428.

Loué, A., 1986. Les Oligo-elements en Agriculture.

Agri-Nathan Intenational, Paris.

Olsen, S.R., Cole, C.V., Watanabe, F.S., Dean, L.A., 1954. Estimation of available phosphorus in soils by extraction with sodium bicarbonate. U.S. Dep. of Agric. Circ. p. 939.

Olsen, S.R., Sommers, L.E., 1982. Phosphorus. p. $403-$ 430. In A.L Page et al. (ed.) Methods of soil analysis. Part 2. 2nd ed. Agron Monogr. 9. ASA and SSSA, Madison, WI

Özkutlu, F., Korkmaz, K., Özenç, N., Aygün, A., Şahin, Ö, Kahraman, M., Ete, Ö., Akgün, M., Taşkın, B., 2016. Ordu-Merkez ilçedeki bazı fındık bahçelerinin mineral beslenme durumunun belirlenmesi. Akademik Ziraat Dergisi, 5(2): 77-86

Richards L.A., 1954. Diagnosis and Improvement of Saline and Alkali Soils. US Salinity Lab., (Ed.), United States Department of Agriculture Handbook, 60:94 California, USA.

Sağlam, M., Dengiz, O., 2013. Kimyasal Toprak kalite göstergelerinin faktör ve jeoistatistik analiz yöntemleriyle değerlendirilmesi. Ege Üniversitesi, Ziraat Fakültesi Dergisi, 50(2): 181-190.

Soil Survey Laboratory, 1992. Procedures for collecting soil samples and methods of analysis for soil survey. Soil Surv. Invest. Rep. I. U.S. Gov. Print. Office, Washington D.C. USA.

Soil Survey Staff, 1993. Soil survey manuel. USDA Handbook No:18, Washington, USA.

Suarez, D.L., Vaughan, P.J., 2001. FAO-salinity laboratory SWS model. Research Report No. 147, 179.

Sürek, H. 2002. Çeltik Tarımı. Hasad Yayıncılık, 240 s., İstanbul.

Taban, S., Çıkı1ı, Y., Cebeci, F., Taban, N., Sezer, S.M., 2004. Taşköprü yöresinde sarımsak tarımı yapılan toprakların verimlilik durumu ve potansiyel beslenme problemlerinin ortaya konulması. Tarım Bilimleri Dergisi, 10(3): 297-304.

Tarakçıŏlu, C., Aşkın, T., Cangi, R., Duran, C. 2007. Nutritional status in some kiwifruit (Actinidia deliciosa) orchards: A case survey from karadeniz region in Turkey. Journal of Plant Sciences, 2(2): 187-194

Tarakçığlu, C., Yalçın, S.R., Bayrak, A., Küçük, M., Karabacak, H., 2003. ordu yöresinde yetiştirilen findık bitkisinin (Corylus Avellana L.) beslenme durumunun toprak ve yaprak analizleriyle belirlenmesi. Ankara Üniversitesi Ziraat Fakültesi Tarım Bilimleri Dergisi, 9(1): 13-22.

Temür, G., 2016. Bazı Çeltik (Oryza sativa L.) Çeşitlerinde silisyumun verim, verim öğeleri ve kaliteye etkilerinin belirlenmesi. Yüksek Lisans Tezi. Ordu Üniversitesi, Fen Bilimleri Enstitüsü, 70 s., Ordu.

Turan, M., Horuz, A., 2012. Bitki Besleme. 3. Kısım: Bitki beslemenin temel esasları. (Ed:Karaman, M.R.), Pelin Ofset Yayınc1lık, s. 123-347, Ankara.

Turan, M.A., Katkat, A.V., Özsoy, G., Taban, S., 2010. Bursa ili alüviyal tarım topraklarının verimlilik durumları ve potansiyel beslenme sorunlarının belirlenmesi. Uludağ Üniversitesi Ziraat Fakültesi Dergisi, 24(1): 115-130.

Ülgen, N., Yurtsever, N., 1988. Türkiye gübre ve gübreleme rehberi (3. Baskı). T.C. Tarım Orman Köyişleri Bakanlığı, Köy Hizmetleri Genel Müdürlüğü, Toprak ve Gübre Araştırma Enstitüsü Müdürlüğü Yayınları, Genel Yayın No: 151, 182 s., Ankara.

Ülgen, N., Yurtsever, N., 1995. Türkiye Gübre ve Gübreleme Rehberi (4. Baskı). T.C. Başbakanlık Köy Hizmetleri Genel Müdürlüğü Toprak ve Gübre 
Araştırma Enstitüsü Müdürlüğü Yayınları, Genel Yayın No: 209, Teknik Yayınlar No: T.66, 230 s., Ankara.

Viets, F.G., Lindsay, W.L., 1973. Testing soils for zinc. copper. manganese and iron. Soil Soc. of Amer. Inc. Madison Wisconcin USA. 153-172.

Webster, R., 2001. Statistics to Support Soil Research and Their Presentation. European J. Soil Sci., 52: 331-340.

Wolf, B., 1971. He determination of boron in soils extracts, plant materials, composts, manures, water and nutrient solution. Soil Science and Plant Analysis, 2(5): 363-374.

Yurtsever, N., Alkan, B., 1975. Karadeniz Bölgesi topraklarının fosfor ihtiyaçlarının tayininde kullanılan bazı toprak analiz metodlarının tarla denemeleriyle kalibrasyonu üzerinde bir araştırma. TÜBİTAK Yayınları No: 220, Toag Serino: 36, Ankara.

Zengin, M., Çetin, Ü., Ersoy, İ., Özaytekin, H.H., 2003. Beyşehir yöresi tarım topraklarının verimlilik durumlarının belirlenmesi. Selçuk Üniversitesi, Ziraat Fakültesi Dergisi, 17(31): 24-30. 